\title{
ПЕДАГОГИЧЕСКИЕ СТЕРЕОТИПЫ КАК ПОКАЗАТЕЛЬ ПРОФЕССИОНАЛЬНОЙ ДЕФОРМАЦИИ ЛИЧНОСТИ УЧИТЕЛЯ
}

\section{PEDAGOGICAL STEREOTYPES AS AN INDICATOR OF PROFESSIONAL DEFORMATION OF THE TEACHER'S PERSONALITY}

\section{E. Alexandrova \\ O. Dutchina \\ T. Alexandrova}

Summary: The article is devoted to the problem of pedagogical stereotypes, which act as an indicator of professional deformation of the teacher's personality. General theoretical approaches to the professional development of teachers, which has stages and crises, are revealed. It is shown that crises of professional formation are sensitive to the formation of professional deformations, provided they are not constructively resolved. Professional deformations are manifested in violation of the ways of activity, in accentuated professional qualities, in the appearance of behavior stereotypes in the activities and communication of the teacher. Pedagogical stereotypes distort the teacher's reflection of professional situations and become the leading psychological determinant of professional deformations of the teacher's personality.

Keywords: professional development, pedagogical activity, professionally important qualities, professional deformation, pedagogical stereotype.

\author{
Александрова Елена Вячеславовна \\ Тихоокеанский государственный университет \\ vacheslavovna@inbox.ru \\ Дутчина Оксана Борисовна \\ К.nсх.н., дочент, Тихоокеанский государственный \\ университет \\ aksa26@mail.ru \\ Александрова Тамара Ивановна \\ К.nсх.н., дочент, Тихоокеанский государственный \\ университет \\ tomalex99@mail.ru
}

Аннотация: Статья посвящена проблема педагогических стереотипов, которые выступают как показатель профессиональной деформации личности учителя. Раскрыты общетеоретические подходы к профессиональному развитию учителя, которое имеет стадии и кризисы. Показано, что сенситивными для формирования профессиональных деформаций педагога являются кризисы профессионального становления при условии их неконструктивного разрешения. Профессиональные деформации проявляются в нарушении способов деятельности, в акцентуированных профессиональных качествах, в появлении стереотипов поведения в деятельности и в общении учителя. Педагогические стереотипы вносят искажения в отражение учителем профессиональных ситуаций и становятся ведущим психологическим детерминантом профессиональных деформаций личности педагога.

Ключевые слова: педагогический стереотип, профессиональное развитие, педагогическая деятельность, профессионально важные качества, профессиональная деформация.

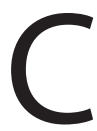

овременные инновационные процессы, связанные с модернизацией отечественного образования, повышают требования к условиям, средствам и технологиям педагогического труда, к личности учителя как к субъекту педагогической деятельности. Личность учителя является ведущим фактором педагогической деятельности, определяющим специфику профессиональной деятельности, профессионального общения и в целом профессионального развития учителя на разных стадиях профессионализации. Педагогический труд учителя относится к эмоционально напряженному труду, поскольку педагоги несут повышенную ответственность за образовательные результаты учащихся, постоянно вовлечены в эмоционально насыщенное общение, подвержены действию множества психологических и социальных эмоциогенных факторов, зачастую решают профессиональные задачи в условиях конфликта ожиданий и давления [5].

Поэтому профессиональная деятельность учителя может быть отнесена к категории повышенного риска с точки зрения формирования педагогических стереотипов и профессиональных деформаций. Проблема педагогических стереотипов как показателя профессиональной деформации личности учителя разрешается в контексте выявления сущности понятий профессиональное развитие, профессиональная деформация, а также общенаучного понимая термина стереотип и проявления его специфики в педагогической деятельности.

Профессиональное развитие учителя раскрывается с позиции системно-деятельностного и системно-генетического подходов, которые позволяют рассмотреть данный процесс, с одной стороны, как процесс становления личностных новообразований учителя - профессиональной направленности, способностей, личностных качеств, умений, навыков, компетенций, с другой стороны - как становление собственно педагогической деятельности, ее мотивационной, коммуникативной и операционально-деятельностной составляющих. Дан- 
ные процессы имеют стадиальность, характеризуются кризисами при переходе от одной стадии профессионального развития к другой [4]. Профессия учителя относится к соционическому виду, в которой предметом труда и главной ценностью является личность растущего человека, а ведущими профессиональными требованиями выступают требования к профессионально значимым качествам педагога. В связи с этим возрастают требования к личности учителя. С этих позиций профессиональное развитие педагога рассматривается как становление, интеграция и реализация его личностных качеств в профессиональной деятельности, ведущие к качественному преобразованию внутреннего мира педагога, к творческой самореализации в профессии [4].

Любая профессиональная деятельность деформирует личность, приводит к образованию социально и профессионально нежелательных качеств и черт характера. Профессиональные деформации отражают нарушение способов деятельности, профессиональных качеств, появление стереотипов поведения и психологических барьеров [2]. Развитие профессиональных деформаций педагога определяется многими факторами, к которым относятся, прежде всего, возрастная динамика, содержание профессии и социальной среды. В процессе профессионализации успешность выполнения педагогических задач определяется степенью развития профессионально важных качеств педагога, которые могут трансформироваться в профессионально нежелательные качества и в профессиональные акцентуации, оказывающие негативное влияние на деятельность, поведение и общение учителя [1]. Профессиональные акцентуации в процессе многолетнего выполнения деятельности профессионализируются и интегрируются со стилем педагогической деятельности, трансформируясь в профессиональные деформации личности учителя [3].

Профессиональные деформации педагога могут возникать на разных этапах профессионализации. Сенситивными для их формирования являются кризисы профессионального становления при условии их неконструктивного разрешения, поскольку такой выход из кризиса искажает профессиональную направленность и инициирует процесс образования профессиональных деформаций [2]. Для учителей, согласно Я.А. Елкиной, наиболее выраженными являются проявления таких форм профессиональной деформации личности, как «сверхконтроль, доминантность, демонстративность, авторитарность, консерватизм» [1, с. 12]. Т.А. Жалагина расширяет этот список, называя педагогическую агрессию, дидактичность, личностно-ролевой диссонанс, социальное лицемерие [2].

В процессе профессионального взаимодействия и профессионального общения с субъектами образовательной деятельности - учителями, учащимися, родителями, осуществляется их восприятие как социальных объектов, которое предполагает оценку, сравнение и отнесение их к определенной категориальной группе с помощью оценочных эталонов и стереотипов. Педагогические стереотипы являются частным случаем социальных стереотипов, которые представляют собой «эмоционально окрашенные, обобщенные, устойчивые, обоснованные общественным и личным опытом, в разной степени адекватные действительности образы целого класса людей, обладающих определенными свойствами»[6, с. 97]. В формировании стереотипов важную роль играют оценочные эталоны, представляющие «субъективные представления человека о социальнопсихологических свойствах, которыми должна обладать личность при выполнении той или иной общественной роли» $[6$, с. 96].

Профессиональные стереотипы являются неизбежным атрибутом профессионализации специалиста. Педагогические стереотипы определяются как «сформировавшихся в сфере обучения и воспитания устойчивых, упрощенных, схематизированных и эмоционально окрашенных представлений о педагогической деятельности, личности ребенка, родителей и самого педагога, создающиеся на основе личного опыта человека, передающиеся от социального окружения в рамках выработанных обществом норм [7, с. 82]. Как отмечает Я.А. Елкина, «образование автоматизированных профессиональных умений и навыков, становление профессионального поведения невозможны без накопления бессознательного опыта и установок. Автоматизированные действия необходимы для успешного выполнения трудовой деятельности, но со временем профессиональное бессознательное может превратиться в стереотипы мышления, поведения и деятельности» [1, с. 34]. Педагогические стереотипы, с одной стороны, имеют положительное значение, обеспечивая определенность реагирования в сложных педагогических ситуациях и относительную успешность деятельности. С другой стороны, педагогические стереотипы вносят искажения в отражение профессиональной ситуации и порождают разного типа психологические затруднения [7], становясь ведущим психологическим детерминантом профессиональных деформаций личности педагога.

Итак, процесс профессионально-личностного развития учителя на определенных этапах выступает не только как развитие и становление, но и как застой, деградация и деформирование личности, что приводит к формированию профессиональных деформаций. Профессия учителя имеет свой комплекс профессиональных деформаций, которые являются неизбежными в процессе его профессионального становления. Про- 
фессиональные стереотипы учителя, с одной стороны, вносят определенность в его деятельность, с другой - искажают ситуации профессиональной деятельности и профессионального общения, являясь причиной формирования педагогических деформаций. Преодоление стереотипизации профессиональной деятельности предполагает использование разнообразных личностно ориентированных технологий, направленных не только на развитие профессиональных знаний, навыков и умений, но, прежде всего, на развитие личности учителя, его личностных и ценностно-мотивационных качеств, творческого потенциала, которые обеспечивают, как высокое качество педагогического труда, так и творческую самореализацию личности учителя в профессии.

ЛИТЕРАТУРА

1. Елкина Я.А. Креативность как фактор профессионально-личностного развития учителя средней школы: дис. ... кандидата психологических наук. - Тверь, 2017. - 218 c.

2. Жалагина Т.А. Психологическая профилактика профессиональной деформации личности преподавателя вуза: дис. ... д-ра психол. наук. - Тверь, 2004. -309 c.

3. Корсаков Ю.В. Профессиональная деформация педагога: пути преодоления // Педагогическое мастерство и педагогические технологии: материалы X Международной научно-практической конференции (Чебоксары, 4 дек. 2016 г.). Чебоксары: ЦНС «Интерактив плюс», - 2016. - № 4 (10). - С. 47-49

4. Митина Л.М. Психология профессионального развития учителя. - М.: Флинта: Московский психолого-социальный институт, 1998. - 200с.

5. Моросанова В.И. Дифференциально-регуляторные основы педагогического взаимодействия учителя / В.И. Моросанова, Т.Г. Фомина // Психологическая наука и образование. - 2012. - № 2. - С. 94-102.

6. Русина Н.А. Изучение оценочных эталонов и социальных стереотипов с помощью семантических измерений // Вопросы психологии, 1981. - №5. - С. 96 $-105$.

7. Сартакова Е.Е. Педагогические стереотипы профессиональной деятельности учителя и проблемы аттестации / Е.Е. Сартакова, ЕА. Обухова, Я.Л. Горкальцева // Вестник Томского государственного педагогического университета. - 2013. - №13 (141). - С. 82-88.

8. Сысоева Е.Ю. Профилактика профессиональных деформаций педагога // Вестник Самарского государственного университета. - 2015 . - №11 (133). - С. 215-219.

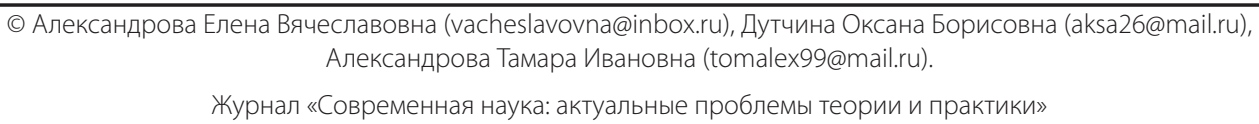

Журнал «Современная наука: актуальные проблемы теории и практики»

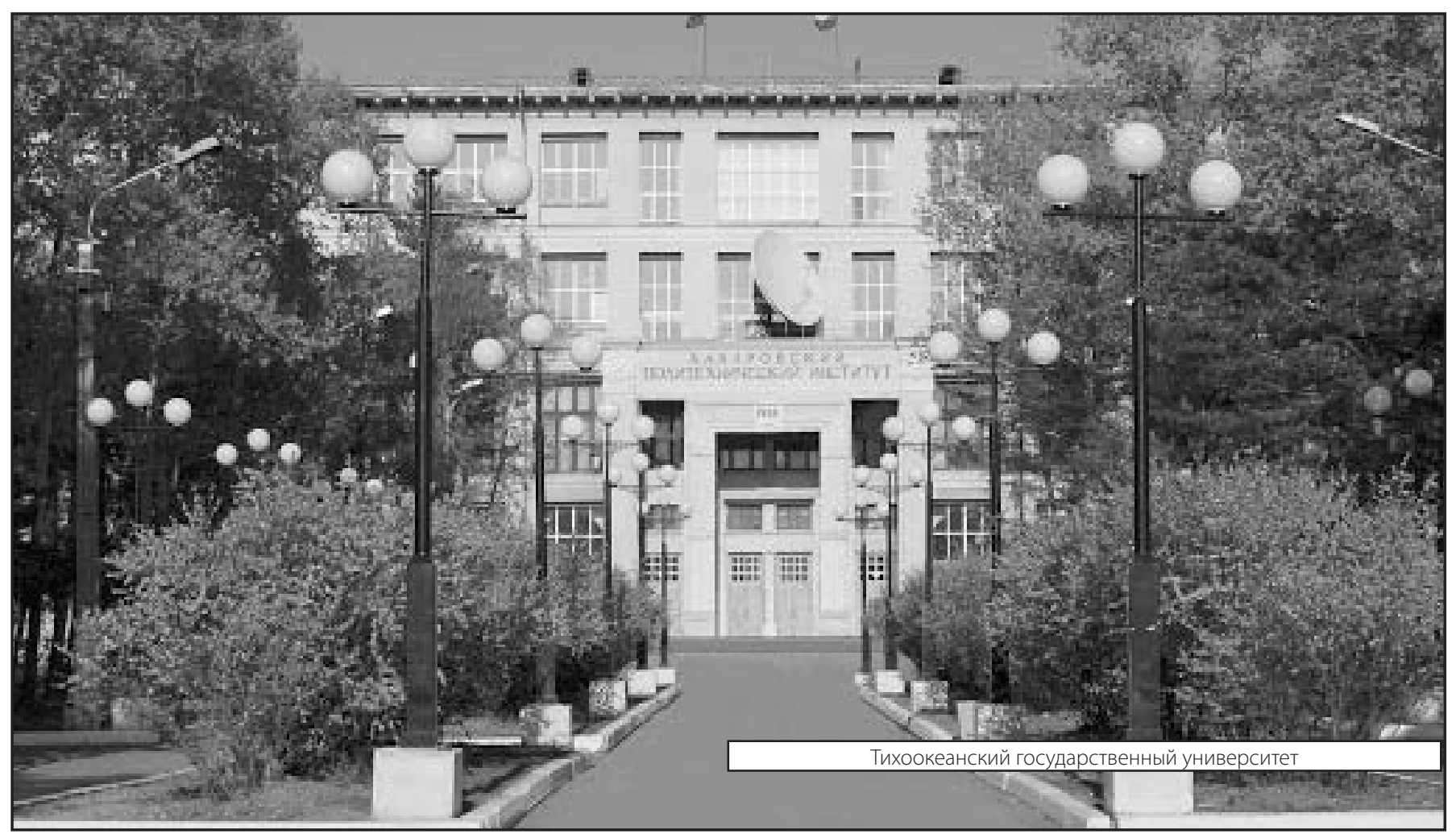

